\title{
Promoting Character Social and Morals through Islamic Educational Values
}

\author{
Ida Umami \\ \{alidaumamimashari@yahoo.co.id
}

IAIN Metro Lampung, Jl. Ki Hajar Dewantara 15A Kota Metro - Lampung, 34112, Indonesia

\begin{abstract}
Character education is aimed at achieving the five goals. Firstly, it is to develop affective potency of the students in their context as human and citizen inheriting their nation character values. Secondly, it is to develop the noble habit and behaviour which are in line with the universal values and the nation religious tradition. Thirdly, it is to strengthen the students' leadership and their sense of responsibility as to the next generation of the nation. Fourthly, it is to develop the students' competency so that they could be autonomous, creative, and possess nationality insight. Finally, it is to develop the school as a good learning environment so that it could support the growth of honesty, creativity, and friendship with the pride of nationality and dignity. The morality education, in turn, lead to a holistic personality possessing a high moral standard in speech, action, attitude, thought, feeling, work, and output which are in line with the religious values, norms, and the noble moral of the nation.
\end{abstract}

Keywords: Character Social and Islamic Educational Values

\section{Introduction}

The endavour to implement the character building is nowadays needed to resolve the moral decadence within the society. Such effort is to keep the most valuable asset of a country, the children. The decadence mentioned embraces such phenomena as free sex, violence, plagiarism, drug abuse, pornography, rape, robbery, expropriation, and other social phenomena that have not been resolved well. The juvenile delinquency phenomenon is coloured by cheating habit, plagiarism, bullying, and gang fight. One of the serious impacts of those phenomena is criminal behaviors. At the same time, the adult behavior is also greatly influenced by the phenomena above in that they like conflict, violence, gang fight, corruption, and betrayal or love affair.

The moral crisis and moral decadence reflect that the whole knowledge about religion and moral that the students learn in the school fail to bring about positive impacts for the Indonesian. Even worse, many Indonesians seem to be inconsistent in that their speech is different from their deed. Many people, then, assume that such phenomenon is a result of the education system in Indonesia. The process of demoralization is rooted in the learning process which is inclined to spread textual moral and behavior content. The students are not prepared to deal with the existing contradictions in life. Thus, it is the education system that contributes 
the strongest influence toward the moral crisis and moral decadence phenomenon.

The formal education in the school is assumed to be a determining factor since it emphasizes more on the intellectual and cognitive domain. Meanwhile, the soft skill and other non-academic aspects, which are the building blocks of the character building, tend to be ignored. As yet, academic parameters have been the main goal of the education. It can be clearly seen in the phenomenon of National Examination (UN) which at once makes it difficult for the character education to be implemented.

The education practice, which is supposed to strengthening the characters and virtues, shows the contradictive results from what it is supposed to reach. In the past time, for example, such subjects as Pendidikan Moral Pancasila (PMP) and religious teaching failed to bring the values of moral and humanism into the students' awareness. The content within the religious teaching focused on the cognitive development instead of the affective and psychomotor formation. The religious teaching, thus, was dominated by textual memorization. Rarely did it touch the social aspect as to how to live in harmony within the society and nation.

It can be said that some aspects within the students like affective and moral virtues tend to be abandoned. According to Koesoema, the commitment to integrate the character education has been the weakest point of the national education policy. In such, many would agree to resolve the moral decadence. The decision makers, doctors, religion scholars, entrepreneurs, educationists, parents, and other elements of the society seem to worry about the same phenomena, character education.

\section{Discussion}

Etimologically, the word character is derived from a Greek word which means "to mark"and emphasizes on the value applications in the form of behavior and action[1]. That is why, when a man is dishonest, cruel, and greedy, he is labeled as to have a bad character. On the contrary, an honest and helpful man is labeled as to have a noble character. Therefore, the term character is closely related to one's personality. A man of character is he who acts with high moral standards.

\subsection{The Concept of Character Education}

Character education has been a polemic in some countries. The pros and cons have been coloring the discourse of character education. Basically, character education is a part of the school responsibility which has been ignored during this time. There has been a very little attention paid to character education while on the other hand it should have been developed seriously within the education system. Character building and academic achievement should be of two integrative missions of the education system. Nevertheless, the existing economic and political atmospheres have kept the schools from building noble character of the students.

The character education could be understood as the deliberate use of all dimensions of school life to foster optimal character development. It implies that a collective action from all the stakeholders is needed in developing the students' character[2]. This could be reasonably done through the development of the content of the curriculum, the process of instruction, the quality of relationships, the handling of discipline, the co-curriculer activities, and the ethos of the stakeholders within the school.

Character education is aimed at achieving the five goals. Firstly, it is to develop affective potency of the students in their context as human and citizen inheriting their nation character 
values. Secondly, it is to develop the noble habit and behavior which are in line with the universal values and the nation religious tradition. Thirdly, it is to strengthen the students' leadership and their sense of responsibility as to the next generation of the nation. Fourthly, it is to develop the students' competency so that they could be autonomous, creative, and possess nationality insight[3].Finally, it is to develop the school as a good learning environment so that it could support the growth of honesty, creativity, and friendship with the pride of nationality and dignity.

Character education has three main functions. First, it functions to shape and develop the students' potency so that they can have a good mind, be kind, and behave in line with the philosophical values of Pancasila. Second, it functions as refinement and strengthening the role of family, educational institution, society, and government to participate and be responsible in developing the citizens' potency within the context of moving toward the developed, autonomous, and prosperous country. Third, it plays a filtering function. It helps the citizens in choosing their own culture and adopting the foreign culture. The three functions mentioned are reached through: (1) strengthening the Pancasila as the philosophy and ideology of the nation, (2) inaugurating the values and norms stated within UUD 45, (3) strengthening the commitment on United Nation of Indonesian Republic (NKRI), (4) strengthening religious values stated within the concept Unity within Diversity (Bhineka Tunggal Ika), and (5) strengthening the nation competitiveness and superiority within the global life context.

From the above explanations, it can be inferred that character education involves all of the efforts that the teacher does to influence the students' character. The teacher helps coloring the students' character through becoming a role model about how to talk, deliver something, tolerate others, and so forth.

Character education as an integral effort to build up the nation character is in need to be impelemented. It has become very urgent in that Indonesia has no other choice but to implement it soon in order to face the regional and global challenge. Among the characters that need to be built up are the character of being capable and the habit of giving the best as an achievement rooted in honesty values. Honesty is the core of the character building, and being noble is the basic character of every person. The basic character is, then, being modified and changed through the process of life. For instance, a lion is basically wild animal that could turn to be tame because of it was trained to be a part of a sircus show. In this point, the lion basic character is said to have been modified.

From the substance and purpose perspectives, character education is more or less similar to morality education since both serve as the media to create a fundamental change in term of human behaviour[4]. The term morality education belongs to English language which in Bahasa Indonesia refers to budi pekerti. The term morality itself covers such domain as: custom, courteousness, and behavior.

To certain extent, character education refers to a plus morality education in its context as an integral part of the school. Its main goal is to develop the students' character and behavior by fully comprehending the existing values and beliefs in the midst of the society[4]. Such comprehension is, then, expected to be a moral power in the students' life in that it will be reflected through such characters as honesty, reliable, discipline, and cooperative. The students are also expected to put forward the affective domain (feeling/attitude) without abandoning the cognitive domain (rational thought) and skill aspects (capable of organizing data, delivering idea, and working together)

The morality is a certain nature and habit possessed by someone as a basic to behave nicely and to appreciate others in life. At the meantime, the human nature is the whole drives, attitude, decision, habit, and moral values. Those entities refer to one technical term, virtue. 
In the operational context, the morality education is an effort to equip the students through counseling, instruction, and training during their growth time. Such effort is meant to create human with a clean heart, good behavior, decent worship to God, and well-behaved response to God's creation. The morality education, in turn, lead to a holistic personality possessing a high moral standard in speech, action, attitude, thought, feeling, work, and output which are in line with the religious values, norms, and the noble moral of the nation.

The character education needs to adopt and enhance the scheme and the pattern implemented in the morality education[5]. Such innovation can be done through the strengthening process of a holistic affective domain development. The process should be conducted continually and gradually within the formal, informal, and nonformal education institution. The affective domain in this context is related to the emotional aspects like feeling, interest, attitude, and the state of being obedient to morality.

The character education should be developed within oneself. It is manifested in a process or an activity aimed at integrating the essential values. Such is based on the assumption that human is a creature who possesses the capability to learn and give meaning to essential values existing in their life. The very fundamental thing within the process of character education is the value integration conducted through broadening the insight on how to live meaningfully[6]. The character education strives create a holistic personality that is capable of speaking skillfully, using the symbol well, respecting aesthetic, and being disciplined.

\subsection{The Correlation among Character Education, EQ, and SQ}

Presumably, many people would ask the impacts of the character education on the academic achievement. Some research had been undertaken to figure out the related answers. The summary of those research were best depicted through a bulletin called Character Educator published by the Character Education Partnership. One's success does not rely only on the cognitive domain and the hard skills, but more on the ability to manage oneself and others or the so-termed soft skill.

Another research shows that one's success is determined by around twenty percent of his hard skill while the rest eighty percent of his soft skill. Furthermore, the most successful people in the world are assumed to be so because of their soft skill rather than their hard skill. The conclusion of the research shows that the quality of character education needs to be improved.

The integration between personality quotient and noble character have been the nature of the character education. This kind of education is an effort to help the students understand, care about, and act in line with the values and ethics. The character education is a plus morality education involving cognitive aspects, feelings, and actions. Without these three aspects, the character education will not be effective. Moreover, the implementation of character education should be continues and systematic. With the character education, a child will be emotionally smart. The emotional intelligence is believed by many to be the most important part of one success in the future including in the academic aspect. A newly published book entitled Emotional Intelligence and School Success compiled various result of related research on the positive influence of emotional intelligence toward the students' success in the school[7]. It is stated that a number of determining factors of the students' failure in the school. Such factors are not located within the brain, but in the students' character like self confidency, the ability to work together, the capability to get along with others, concentration level, emphaty, and communication skill.

The experts in the field have identified five characters of those who have a good emotional intelligence[8]. They are: 
1. Self-awareness. It is the ability to recognize emotion and its causal factors. One possessing a good emotional intelligence is able to evaluate himself and is able to search related information before doing something.

2. Self-regulation. It is the ability to control oneself and to act carefully. A man with such character will not let his emotion take control over himself.

3. Self-motivation. When a thing does not go according to a plan, the man will not ask himself, "What is wrong with me?," instead he will be asking, "What should I do to fix this problem?"

4. Empathy. It is the ability to recognize other's feeling and experience what others feel.

5. Effective relationship. With the four characters mentioned above, one can communicate with others effectively. The ability to solve a problem together is preferred than to involve within trivial confrontation. A man with a high intelligence level tends to possess constructive purpose in his mind.

Generally the concept of emotional intelligence covers some other characters namely: selfawareness, mood management, self-motivation, impulse control, and people skill. Daniel Goleman maintains that emotional intelligence (EI) embraces five following domains:

1. Knowing your emotions;

2. Managing your own emotions;

3. Motivating yourself;

4. Recognizing and understanding other people's emotions; and

5. Managing relationships, ie, managing the emotions of others.

The emotional intelligence is needed to succeed in getting along with others, interacting, working, pursuing career. Therefore, it should become an integral part within the process of integrating noble characters. The emotional intelligence should go hand in hand with intellectual intelligence, and spiritual intelligence.

\subsection{The Correlation between Character Education and Morals}

Moral education is closely related to the information of ideal criteria and the sources of the noble character. Thus, the combination of those two things mentioned is an interesting offer. This illustration becomes, at once, an entry point to state that the education character has something to do with the spirituality values.

The term moral or akhlak arises as a mediator connecting the Creator (Khalik) and the creature. The connection between the two is reciprocal, or it is widely known as hablum minallah. The verbal product of hablum minallah commonly results in another relationship pattern called hablum minannas[9].

Ibnu Athir, in his book entitled an-Nihayah, states that the term khuluq refers to the human spiritual description (the spirit and its nature), while khalqu refers to the physical description like face form, skin colour, and body height.

In line with the notion proposed by Ibnu Athir, Imam al-Ghazali also asserts that when people state that a person is good in term of his khalqu and khuluq, the person is good in both his spiritual and physical forms. From the two statements above, it can be inferred that the term akhlak might be understood as, in Bahasa Indonesia, as kesusilaan, sopan santun, and tata karma. Meanwhile, in English language, this concept is similar to moral and ethic.

Al-Ghazali defines akhlak as a set of behavior and nature which tends to permanent within oneself. It becomes a source where certain spontaneous or automatic actions or behaviors come from. Such definition is also in line with the one stated by Ibn Maskawih in that he 
states that akhlak is a state of mind and soul where an action comes out from without a due consideration[10].

The term akhlak can be understood as a purposely conditioned will, wish, or desire. When a person determines to make an action a habit, such habit is then termed as akhlak. The will, wish, or desire is a set of repeated decision or determination so that it is easy to do. Each decision or determination possesses a power so that when it is done repeteadly it will result in a bigger or stronger power. Such magnificent power is then called akhlak. Under condition where akhlak is related to good deed, it is called akhlakul karimah. On the contrary, when it deals with bad action, thought, or attitude, it is called akhlakul mazmumah.

\section{Conclusions}

The most obvious indicator reflecting the critical condition of the character decadence can be seen in the children's behavior. More and more children pay less respect to their parents, teachers, and other people they are supposed to respect. More, uncivilized action, cheating, and lie can be found easily in the midst of the society. These phenomena are very disquieting in that all elements of the society should become alert. To cope with this, some parents send their children to a special school or the school with a plus additional content, while some others prefer to teach their children at home by themselves.

The issues around the character education or morality are not totally ignored by the education institutions. Nevertheless, some facts reflecting the moral decadence show that a serious problem has happened in the education system. The problem shows the failure of the education system in that it should be resolved soon in order to make the Indonesians much more civilized by possessing the noble characters. To certain extent, it should be admitted that the religious knowledge and the morality lesson learned by the students from the school have not yet brought an optimum impact upon the characters of the students. The content of the lessons is all appropriate, and even the students could understand and memorize it well. Nevertheless, not all of the teachers pay a very serious attention on the importance of the character education. All teachers, regardless the subjects they are teaching, should have taken the issues of character into account.

Nowadays, the parents should work hard and involve in the process of the character education so that the children would be able to think, behave, and act in line with the accepted morality. The character education could be started by broadening and developing the children's awareness to possess a good morality because when the children do not have such awareness, they would act randomly. This in turn would bring a negative impact toward their pshycologial growth. Moreover, it has been widely known that a good character can be measured through a good 'action' and not only through a good 'thought'. When the children's emotional intelligence develops, they will have a noble character and finally will be able to act appropriately. Early beginning of introducing the character education to the children might be the most appropriate way to build up their morality, now and forever.

A positive and noble character will enhance a person's status. On the other words, a person's status relies much on his character. In fact, character is so very important in that it makes a person strong and tough in facing the life problems and to live a better life. Character also makes marriage life better in that the couple can teach and condition their children to matured, responsible, and productive individuals.

The simultaneous and holistic development of intellectual quotient (IQ), emotional quotient (EQ), and spiritual quotient (SQ) is badly needed and should be the responsibility of all stakeholders of education. Any effort to educate people within the family, school, and 
society environment should pay attention to the importance of the combination of the three quotient mentioned above.

The education system, from the elementary level until higher education level, has been supposed to emphasize more on the students' academic aspects in that it focuses more on transferring knowledge stimulating and nurturing the brain and the intellectual potency only. The education system should have involved more aspect on the emotional intelligence for it embraces some important characters like integrity, honesty, commitment, creativity, mental strength, wisdom, justice, and self management. The character education would also lead person to be humble, loyal, tolerant, patient, fair, and simple.

It should be underlined that the character or plus morality education is very urgent. The implementation of the character or plus morality education should consider the unity of the human nature that is supported by three quotients (they are IQ, EQ, and SQ). The character education is expected to arouse the ability of offering spiritual sense about thought, behavior, and action as well as to comprehensively blend IQ, EQ, and SQ in harmony.

\section{References}

[1] J. . Cartledge, G. and Milburn, Teaching Social Skill to Children; Innovative Approach. New York: Pergamon Press, 2000.

[2] F. bin A. A. Al-Syalhub, Quantum Teaching. Jakarta: Zikrul Haki, 2005.

[3] D. \& Whelan, Moral Development. Dubuque: WM.C.Brown, 2005.

[4] F. R. and J. S. Biehler, Psychology Applied to Teaching. Boston: Houghton Mifflin Company, 2007.

[5] J. H. Ballantine, The Sociology of Education, A Systematic Analysis. New Jersey: Prentice-Hall, 1983.

[6] N. Noddings, Philosopy of Edication. USA: Westview Press, 2000.

[7] and J. F. T. Elliott. N Stephen, Thomas R. Kratochwill, Joan Littelefield, Education Psychology Effective Teaching, Effective Learning. Madison: A Times Miror Company, 1996.

[8] D. Combs, Arthur W, The Professional Education of Teacher; a Humanistic Approach to Teacher's Preparation. Boston: Allyn Bacoon, 2000.

[9] B. G, Effective Teaching Methods. New York: Merrill, 1992.

[10] T. H. B. Al-Attas, Muhammad Naquib, The Concept of Education in Islam: A Framework for an Islamic Philoshophy of Education. Bandung: Mizan, 2004. 